\title{
In the wake: postcolonial migrations from the Horn of Africa
}

Derek Duncan

\begin{tabular}{|c|c|}
\hline Date of deposit & 01082019 \\
\hline Document version & Author's accepted manuscript \\
\hline Access rights & $\begin{array}{l}\text { (c) The Author(s) } 2019 \text {. Published by Oxford University Press for } \\
\text { the Court of the University of St Andrews. } \\
\text { All rights reserved. This work is made available online in } \\
\text { accordance with the publisher's policies. This is the author } \\
\text { created, accepted version manuscript following peer review and } \\
\text { may differ slightly from the final published version. }\end{array}$ \\
\hline $\begin{array}{l}\text { Citation for } \\
\text { published version }\end{array}$ & $\begin{array}{l}\text { Duncan, D. (2019). In the wake: postcolonial migrations from the } \\
\text { Horn of Africa. Forum for Modern Language Studies, 56(1), } \\
\text { [cqz055]. }\end{array}$ \\
\hline $\begin{array}{l}\text { Link to published } \\
\text { version }\end{array}$ & https://doi.org/10.1093/fmls/cqz055 \\
\hline
\end{tabular}

Full metadata for this item is available in St Andrews Research

Repository at: https://research-repository.st-andrews.ac.uk/

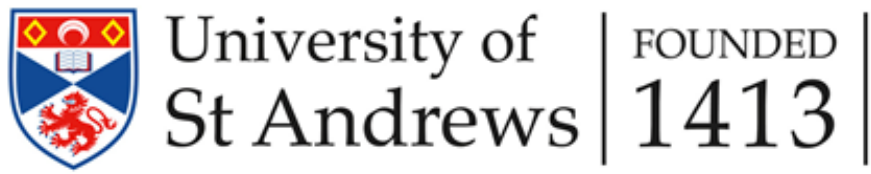


In the Wake: Postcolonial Migrations from the Horn of Africa

\begin{abstract}
Abu Bakr Khaal's African Titanics (written in Arabic) and Jonny Steinberg's $A$ Man of Good Hope (written in English) track diasporic movements from the former Italian colonies of Eritrea and Somalia. Focussing on mobility rather than memory, both books trace complicated and unpredictable patterns of forced displacement and precarious settlement. African Titanics charts the journey from Eritrea to the shores of the Mediterranean and the sea crossing to Europe while A Man of Good Hope follows the movement overland from Somalia to South Africa. Both texts delineate communities networked across national borders and propose an alternative geography formed by cultural commonality rather than geopolitical division. The essay draws on Christina Sharpe's concept of the 'wake' as a means of understanding how migrant subjectivity and community are formed through the multiple forms of racialised violence experienced in transnational mobility.
\end{abstract}

\title{
Keywords
}

Italian postcoloniality; transnational mobility; migration; Eritrea; Somalia; the wake; creative practice

Look, this ain't entertainment, it's for niggas on the slave ship These songs just the spirituals, I swam against them waves with Ended up on shore to their amazement

Now I hope the example I set's not contagious

Lock us behind gates but can't tame us

Used to be stay safe, now it's stay dangerous

'Cause ain't no point in playing defense nigga

That's why I dove off the deep end nigga

Without a life jacket. ${ }^{1}$ 
These lines from Nipsey Hussle's track 'Dedication' make visible a probably unexpected alignment between patterns of Black life and death in the US and the global diaspora of postcolonial Italy. 'Dedication' explicitly recalls the history of Black disempowerment in the US, and praises the ongoing work of resistance 'against them waves'. However, the image in the final lines of diving into the water 'without a life jacket' extends the compass of the lyrics beyond the Black Atlantic to suggest their possible relevance to the contemporary Black Mediterranean. ${ }^{2}$ Referred to by Loris de Filippi, President of MSF in Italy, as a 'mass grave', ${ }^{3}$ the Mediterranean has become a mortuary for thousands of people attempting to reach Europe at great personal and financial cost. Many of those attempting to cross are from Eritrea as well as from neighboring Somalia and Ethiopia, nations whose borders were formed largely by Italy's colonial occupation. ${ }^{4}$ This unexpected alignment was however already present in the rapper's family history. Fleeing the ongoing war between Ethiopia and his homeland, his father, Dawit Asghedom, moved to the US from Eritrea in the mid1970s where he met Angelique Smith, the African-American woman with whom he raised their two sons Ermias (Nipsey Hussle) and Samiel (Blacc Sam), and daughter Samantha. Dawit took both his sons as teenagers to visit the former Italian colony where they returned to media acclaim in 2018 even meeting the controversial president Isias Afwerki.

The patterns drawn in 'Dedication' between apparently separate instances of Black oppression anticipate Nipsey Hussle's fatal shooting in Los Angeles on 31 March 2019. From an American perspective, his murder is symptomatic of what Saidiya Hartman has called 'the afterlife of slavery skewed life chances, limited access to health and education, premature death, incarceration, and impoverishment. ${ }^{5}$ Yet it needs also to be figured as a discordant element in what Cristina Lombardi-Diop and Caterina Romeo refer to as the 'transhistorical and geographically expansive nature of postcoloniality in the Italian context', the disparate and often forced movements of people through colonial conquest, and transnational and internal migration. ${ }^{6}$ Slavery's afterlife and Italian postcoloniality are also, amongst other things, ongoing contemporary articulations of historical divisions grounded in modes of racialised thinking and practice, and share, albeit differently, a self-reflexive relationship with the 
African continent. Christina Sharpe's In the Wake: On Blackness and Being provides the critical tools for binding more tightly the two strands of Nipsey Hussle's personal and family history. ${ }^{7}$ Primarily an indictment of the violent, injurious aftermath of slavery that continues to imprint Black life in the US, its argument expands to reflect on the perils of Blackness in a global context. Beginning her critique with a detailed account of her personal and familial positioning in slavery's homicidal wake, Sharpe pursues doggedly the image of the 'wake' invoking both a metaphorical understanding of the wave-trail behind the slaver itself and the literal, enduring labour of mourning and commemorating the dead. ${ }^{8}$ Moving beyond too linear an understanding of slavery's geopolitical legacy, she dedicates a significant part of her book to the wake's expansive presence: 'Living in the wake on a global level means living the disastrous time and effect of continued marked migrations. ${ }^{\prime 9}$ Linking the death of migrants in the Black Mediterranean with life conditions for Black people in the contemporary US, she creates a compelling connection to Nipsey Hussle and his work.

Sharpe tightens that connection through her insistence that to live in the wake is to be critically conscious of its presence, and alert to at least the possibility of thinking constructively beyond its defining ballast. While the pernicious scripting of Black lives, or what she calls the 'orthography of the wake' remains inescapable, Black subjects in the wake may draw on their own cultural traditions and practices of creative labour and resilience to contest, in full critical consciousness, logics of anti-blackness. Black life and humanity subsists in, and through, multiple forms of cultural production 'that take up the wake as a way toward understanding how slavery's continued unfolding is constitutive of the contemporary conditions of spatial, legal, psychic, and material dimensions of Black non/being as well as Black aesthetic and other modes of deformation and interruption'.10 Nipsey Hussle inhabits the wake therefore not just as a victim, but enters its space as a critical creative practitioner and political archivist of Black lives.

\section{Writing the Wake}


In this vein, what follows is an analysis, from the perspective of the wake, of two contemporary African narratives written at the historical intersections of Italian postcoloniality and Black transnational mobility. They articulate the wake's expansive geopolitics and aesthetics in that their subjects set out from the former Italian colonies of Eritrea and Somalia, yet Italy and its legacy do not determine their trajectories. Neither text is written in the colonizer's language, nor does Italy appear to be a particular point of reference. ${ }^{11}$ My argument is that Sharpe's conceptualization of the wake as a space of critical global encounter offers a necessary supplement to a solely Italocentric approach to the postcolonial afterlife of the Horn of Africa.

Abu Bakr Khaal was born in Eritrea and lived in exile in Libya for a number of years. In 2011, he spent several months in a Tunisian migrant camp, before crossing to Europe and now lives in Denmark. African Titanics was first published in Arabic in 2008 with the English translation appearing in $2014 .^{12}$ This short novel begins and ends in Eritrea, but relates, largely in chronological order, the narrator's hazardous land journey across the Sahara and time spent in Libya and Tunisia waiting for a vessel to take him across the Mediterranean. It focuses on the hardships inflicted on the narrator and his companions who come from all over Africa and the Middle East, but is interspersed with references to past lives, poetry and creative story-telling, as well as premonitions of catastrophe and redemption. The reader is also introduced to Malouk whose poetry, music, and fantastic accounts of his travelling forebears will inspire the narrator's own departure from realist, testimonial narrative as he imagines worlds beyond his present beleaguered life. The novel ends with a short poem composed by Malouk after his unconfirmed death, no body having ever been recovered or identified.

Jonny Steinberg is a white South African journalist and academic whose work characteristically fuses history and biography, participant observation, and testimony. A Man of Good Hope: One Man's Extraordinary Journey from Mogadishu to Tin Can Town (2015) is based mainly on an extended series of interviews/conversations with Asad Abdullahi, a Somali migrant in South Africa between October 2010 and September 2011.13 The title truncates Asad's journey which ultimately takes him to Kansas after his stay in Blikkiesdorp, the 
relocation camp outside Cape Town. Steinberg charts Asad's flight from Mogadishu as a child in 1991 following the overthrow of Siad Barre's government, the years spent in camps, with distant family members, and on the street in Kenya and then Ethiopia where he married his first wife. After traveling overland to South Africa, he set up a series of precarious businesses with the help of members of the diasporic Somali community, and was the victim of violent assaults as well as witness to the murders of close friends and associates. ${ }^{14}$ Steinberg's initial research project had in fact been an investigation into the xenophobic violence that spread across South Africa in the spring of 2008. The book's concluding section deals with Asad's formal award of refugee status, a categorization that allows him to apply successfully to migrate to the US, the focus of the book's Epilogue.

Both authors are aware that they write in the shadow of what Sharpe calls the 'dysgraphia' of noxious scripts which mark Black lives. A short paragraph in African Titanics indicts Italian state television's routine portrayal of death in the Mediterranean:

The Italian RAI channels always began their broadcasts with reports of shipwrecks and images of men and women plucked from the waves. Rows of drowned corpses were routinely displayed, carelessly covered over as though victims of a street brawl. As the camera travelled over their faces, the terror and misery they had suffered was instantly apparent. ${ }^{15}$

The reiteration of these images generates the sense of a permanent state of being rather than a singular loss of life. The narrator inserts this paragraph into a description of how he and his companions in Tripoli flick between satellite television channels to find the latest weather forecast comparing different prognostics and how possible variations might impact on imminent departures and crossings. He returns to this representational logic of suffering a couple of pages later talking about the mimetic charge of such scenes on the bodies of his fellow travellers as they approach the ramshackle boats that will carry them out into perilous waters of the Mediterranean: 'their faces would be contorted by abject terror' (p. 61). The physiological effects of this terror are described in 
detail as passengers lose control of their bladders and bowels, some throwing themselves overboard in anticipation of certain death. ${ }^{16}$ Panic and hostility are interrupted by singing as people lose consciousness, or are transformed into savage, cannibalistic monsters: 'You watch them fighting to the death, bent on destruction with every fibre of their beings. They have become animals, and you fear that you have become one too' (p. 62).

Writing in 2012, Steinberg pledges 'to document, baldly and without adornment' what Asad had experienced during the time of their collaboration. ${ }^{17}$ The period was characterized by the return of xenophobic mob violence with Asad's property and family persistently threatened and attacked. The South African police refused to support and indeed targeted the besieged Somali community, regularly imprisoning its members and failing to investigate crimes perpetrated against it. Steinberg reports the following incident that took place during a gang riot:

At the very time the police were all over Blikkiesdorp, a Somali child, aged ten, was found hanging from the clothesline by her own jersey in her parents' yard. She had gone out in the morning to buy a cold drink. Her mother, who had begun to worry because her daughter had been gone a long time, walked out of the shack into the yard and saw her swinging. (p. 297)

The reader infers that she had been lynched; the authorities' subsequent imputation of suicide exonerated them and indicted black migrant culpability. The following day Steinberg took a local radio journalist to the township to report on the incident and was left bereft at the banality and indifferent tone of the broadcast report. The following paragraph's concluding sentence reiterates Khaal's indictment of the 'deep inadequacy 'of Italian state television's visual dysgraphia of the Black Mediterranean:

As I listened, I was struck by the deep inadequacy of news. How does one convey the enormity of what had happened? Thousands of listeners, in the bubbles of their cars, made their way home in the rush-hour traffic. 
Somewhere on the edge of the city, locals had a go at foreigners. The police were not terribly interested. That is how it is. (p. 298) 18

Conversely, as I will show, neither author accepts that this 'is how it is', and instances of resistant orthographies of the wake occur throughout both texts.

\section{African Titanics: writing out of the wake}

In contrast to the cultural nationalism of the language of state media, collective migrant resistance is characterized by informal, quotidian practices of linguistic adaptation and translation. One of the first instances of resistant 'wake work' occurred during the Middle Passage when enslaved Africans with no common language succeeded in inventing creative strategies for communication. Sandro Mezzadra and Brett Neilson expand on this historical practice to encompass the ability of migrants under duress to speak across languages in 'improvised patois' underscoring the political potential of vernacular practices of translation. The result is the creation of 'a language that is common precisely because it is forever in translation and rooted in material practices of cooperation, organization, and struggle'. ${ }^{19}$ Commenting on multilingual traces in recent fiction from the African diaspora, Pier Paolo Frassinelli refers to Naoki Sakai's concept of the 'nonaggregate community of foreigners' to convey the sense of transnational linguistic and affective identification that constructs border-crossing communities. ${ }^{20}$ In both African Titantics and A Man of Good Hope, linguistic suppleness proves an essential tool for survival. Asad depends on his ability to navigate complex linguistic economies as he learns and perfects new language competencies as he travels. The text also contains words from languages other than English that effectively demonstrate the inadequacy of a single tongue to convey his experience. In African Titanics, the travellers' native tongues might be Amharic, Tigré, Hausa, or Wolof, yet the transnational and hence translingual dimensions of the migrant experience are expressed in the common idioms of Arabic, French, or English. One of the narrator's most precious possessions is his pocket English dictionary. Malouk, the novel's poet, speaks in 'flawless English' (p. 76). Yet silenced bodies also speak effectively in translation. To 'resort to 
mime' (p. 51) in the enclosure of the building where the migrants wait for their ship is an act of defiant and collective survival, and consolation is offered in the universal language of human emotion' (p. 52). As the narrator sifts through 'scattered objects' (p. 44) left by previous travellers in the enclosed courtyard, he happens across a letter written in English some years before relating the hazardous journey from Nigeria to the Libyan coast. He and Terhas, his female companion, read the letter, surrogates for the intended recipient who may never have found out what happened to its sender. Later that evening, the narrator finds Terhas on the verge of tears reading short messages inscribed on the kitchen walls by migrants waiting to leave. In this period of suspended time, those waiting expressed their doubts, fears, and hopes in a multilingual patchwork of shared experience, some, but not all, of which the two readers are able to decipher. Some messages are dated, some named, and some selfconsciously signed 'anonymous'. The punctuation of these 'melancholy messages' by the 'odd amusing one' (p. 47) is not redemptive, but joins with the others in the determined address to an afterlife.

These fragments echo the temporalities of Malouk's stories and poems of resilience, fear, and quotidian violence woven into the main narrative. He imaginatively invokes two of his ancestors also called Malouk. ${ }^{21}$ The first, a poet like his descendent, drowned, but becomes the stuff of legend as fishermen claim still to see his ghostly vessel. This story anticipates the book's final chapter that recounts the spectral afterlife of the present-day Malouk presumed drowned in the Mediterranean. He haunts the narrator's dreams, yet rumors of Malouk, as well as traces of his poetic voice, seep across internet chat-rooms. Malouk the Second, also a great story-teller, 'travelled into the future and bought prophecies back with him' (p. 99) disrupting conventional inhabitations of temporality. Words traverse generational boundaries, and Malouk's own poem, 'Crossing', immediately follows with hopes of 'an amulet/To cross/Straits of fire/ Towards continents of snow' (p. 101). The book ends with one of Malouk's posthumous songs that affirm his presence in the wake:

To all the pounding hearts

In feverish boats 
I will cut

Through these paths

With my own liberated heart

And tell my soul

To shout of your silenced deaths

And fill

Palms of dust with morning dew

And song (p. 122) 22

The text is shaped by a similar determination to speak of 'silenced deaths'. The final pages of the penultimate chapter detail the narrator's reimagining of the horrors of Malouk's sea journey and his death. Almost at once the boat begins to take in water as the passengers try to combat the effects of the weather and the waves. Two of the dead are thrown overboard: 'In the morning, the bodies reappeared, floating alongside the boat. Black clouds gathered overhead and storms enveloped the boat once again, lashing it relentlessly as rain poured down for hours on end' (p. 110). A commercial steamer comes into sight:

'Lets throw out one of the corpses so they can see what state we're in!' Malouk suggested. They hoisted up a woman's body and threw it into the water. But the steamer continued on its course and the sailors remained on deck, their arms folded across their chests smiling and sniggering ( $\mathrm{p}$. 110)

One passenger throws himself into the sea in despair; his body does not come back to the surface. The boat is finally overtaken by the 'fateful wave' that sinks the ship sending Malouk to his death. The chapter closes with a poem composed by Malouk in 'those terrifying moments' written, therefore, in the fullest consciousness of the wake. In response to inhuman indifference, he too addresses the Sea: 'In the name of the faces/Etched on your memory/In the name of those/Who have imprinted their cries/On the air' (p. 113). The commemorative hope invested in the Sea stands at odds with the 'unnamed boats/Like unmarked graves' in which the travellers had invested. ${ }^{23}$ For just like the purloined slaves of the Middle Passage deemed to be of material not human 
value, 'Civilisation crucifies them/Above the border's barbs/Their corpses are raised high/Like plunder' (p. 114).

Throughout In the Wake, Sharpe returns insistently to the contemporary Mediterranean. She underscores the financial nature of the Mediterranean traffic, and its echo of the transatlantic slave trade, mostly tellingly unraveled in the legal debates over the cargo, or 'plunder', of the infamous slave ship Zong. ${ }^{24}$ Yet the primary point of reference is contemporary. She specifically recalls the shipwreck of 3 October 2013 in which over 360 people (mostly Eritrean) died, many of whom suffocated under deck. ${ }^{25}$ The details of the sinking itself (the deliberate setting fire to the ship and the reluctance to assist) underscore the lack of human value attributed to the 'silenced deaths' on board. ${ }^{26}$ Moreover, Khaal's description of the sinking of Malouk's boat uncannily rehearses the unfolding of events on the Zong and the sinking of 3 October 2013, yet his work ensures the silent dead an afterlife.

\section{A Man of Good Hope: being in the wake}

If the dominant trope as well as reality of African Titanics is the ship itself, in $A$ Man of Good Hope it is more specifically the hold, or the enclosure of the camp. Indeed, for most refugees from the Horn of Africa fleeing to neighboring countries such as Kenya, Sudan, and Yemen, the UNHCR camp is the defining space of their experience rather than the sea passage to Europe. ${ }^{27}$ The camp determines Asad's status as a state-less subject. While it offers him both an element of sustenance and protection as well as the possibility of escape, its habitation underlines his lack of citizenship. He embodies what Frassinelli describes as 'the precarity and vulnerability of the mobile identities and communities shaped by the experience of migration. ${ }^{28}$ In order to effect this escape from the camp, he needs an identity which allows him to transcend the limitations of his circumstances, and in a sense, invent a new self. Whereas Malouk creates myriad worlds of fantasy, Asad's story must be singular. It is trained on a particular version of the past in order to obtain a particular future. Steinberg met Asad six months after he had moved to a township under the auspices of a UNHCR resettlement programme through which he hoped to gain 
entry to the US. As an established South African writer, Steinberg possesses cultural and economic capital. He reads widely about Somalia and the Horn of Africa, and consults contemporary historians and political scientists. Not only is he able to pay for his story, he is able to travel easily to Europe and Africa to visit places where Asad had lived and meet people who knew his family. These trips allow him to corroborate or revise the narrative, and he is able to gather information about family members and its history which Asad himself doesn't possess. This information about the family's origins and its diasporic displacements after 1991 as well as Asad's lack of knowledge about them are once more fashioned in the wake. He discovers that Asad's parents were not from Mogadishu as he had believed, but from the Ogaden region of Ethiopia where he had spent some months. The knowledge that his parents were, like him, refugees strikes at Asad's sense of self. They 'also had to run from place to place, knowing no home' (p. 309).

Throughout the text, Asad speaks self-consciously as a refugee. Genuinely fearful of the violence directed at him and his business ventures in South Africa, he applies for a 'refugee card' as the first step in plotting an escape. Asad's assumption of a bureaucratized identity leads to an extended interview with US immigration officials in which he recounts in detail 'a carefully crafted story about his life. He did not lie; he described faithfully and in great detail the incidents of violence to which he had been subject since coming to South Africa' (p. 300). Steinberg notes that Asad omits the array of apparently contradictory choices that might more accurately be attributed to a resisting 'border-crossing agent.'29 He chooses instead to become the diminished protagonist of the narrative proffered to the immigration officials which 'whittled away at the flesh of his being, leaving only a stick figure, a hapless refugee' (p. 300).

The 'hapless refugee' is later characterized more fully in terms of the wake:

A refugee has lost control. Great historical forces have upended him and he no longer has a place in the world. He has become an in-between sort of being, suspended between a past in which he belonged somewhere and a future in which he might belong somewhere once more. But for now he 
is in abeyance; he is swept this way and that, like flotsam in a tide. (p.

The refugee is both out of place and out of time, a spectral presence, with none of the allure of Malouk's travelling spirit in African Titanics. As 'flotsam', he is merely wreckage, debris, floating cargo. But it is through the brute fact of being 'in abeyance' and its implication of a suspension of personhood that the refugee's desolation is most surely enacted. As mentioned above, one of the ways in which Asad negotiated and expressed his resilience and entrepreneurship was through his ability to acquire and operate across multiple languages. At points, however, he is dispossessed by them. As he queues one day in Port Elizabeth to apply for asylum-seeker status, he hears brief bursts of Swahili, Amharic, and Somali: 'It was as if fragments of his own biography had taken audible form and were now being thrown at him, as if a random selection of memories had left his head and found their way to the tongues of others' (p. 185). The violence perpetrated against him constantly threatens his erasure. After the riots of 2008, he realizes that 'he was falling back into his own past' (p. 273), housed in yet another camp. Struggling to remain a 'border-crossing agent', he 'was no different from his duffel bag' (p. 147).

Steinberg finally comes to realize that Asad does not want his book. The book requires Asad to remember and see himself as this 'hapless refugee'. Reading the transcript of his memories reveals the loss of his humanity 'this boy kicked through life like a stone; the reading strips him of his guard ... Seeing his life this way is breaking his heart, he reports. He is afraid to read further, lest the lost boy in the camp creep inside him and install himself forever' (p. 278). 'Everywhere, it is loss, loss, loss' (p. 326), he remonstrates, unable to bear the traumatic sight in print of the names of all those he had indeed lost. Steinberg's finely wrought prose chaffs against the form of Asad's recollection. Attempting to cross the Zambian border, 'things went badly, and his memories of the next few days come in the form of flashes and scenes and spectacles, the connections between them not entirely clear ... Asad's memory dissolves, or, at any rate, his will to recall fades ...' (pp. 158-59). To go backwards to Somalia is unthinkable: 'I knew that if I went back there life would be the same, the same, until I die. To be able to wake up in the morning is to keep that possibility of something different 
alive' (p. 231). Waking up in South Africa means that he will not remain indefinitely 'in abeyance'. In retrospect Steinberg recognizes that Asad's transformative, yet silenced, ambition put pressure on the refugee narrative. It was ambition for a desired future with no clear referent: 'I wanted to travel, I just wasn't sure where to' (p. 215). Asad's propensity to court risk 'so that his children and their children and their children in turn live lives nobody in Somalia at the time of his own birth could have imagined' is transformative (p. 313). The text hints at other inexpressible lives: 'he desired more than anything to be a husband and father, but not in the world he knew. He would have to burst through a wall and into another world' (p. 245). These other unrealized narratives are 'wake work as a praxis of imagining'. ${ }^{30}$

Asad's desolation in this world is played out in the same 'wake of violence' (p. 323) as Sadicya, his second wife and her son Musharaf. He had met them in the homeless camp after the first outbreaks of anti-Somali violence in 2008: 'It struck him that they were dying. Not literally: they were not mortally ill. But in their future lay death' (p. 276). Sadicya belongs to the Galgale, an outcast Somali group further and more brutally marginalized after the overthrow of Siad Barre. In 1991, hundreds were forced into the football stadium in Mogadishu and slaughtered. ${ }^{31}$ Steinberg only realizes the depth of her isolation in Kansas when he accompanies the family to a doctor's appointment for their sick baby daughter:

Sadicya is on the couch next to Rahma. Her body is turned from her daughter, her chin is lifted. And her gaze is fixed on something in another world. She is here but not here. The howls that fill the room are background noise (p. 322).

Unlike the other Somali women Steinberg sees in the US who seem to be leading full, active lives, Sadicya appears increasingly withdrawn, disengaged from the tasks of looking after the house and the children. The representation of Sadicya (for it is Steinberg who contends that the howls filling the room are "background noise') extends through the wake to recall that of Aereile Jackson, discussed in Sharpe's dissection of the documentary film The Forgotten Space (2010). ${ }^{32}$ 
Aereile Jackson, the only Black person in the film to speak, appears in a segment dealing with displaced communities near Los Angeles. While the unemployed white men featured are identified in terms of their previous professions, she appears in the credits as 'former mother', a reference to the fact that her children, the loss of whom she embodies and acts out, had been taken from her. Through the anguished temporality of disavowed or disallowed maternity, Sharpe returns to Black abjection: 'What does this phrasing of "former mother" to describe a woman whose children had been taken from her (and likely placed into "care") tell us about the afterlives of slavery and the afterlives of property?'33 Saidicya's abjection is figured through the haunting temporality of the 'former mother'. While she is still with her children, it is Asad who looks after them. The reasons for their marriage remain opaque, and Asad resists Steinberg's attempt to find its psychological resonances in his childhood trauma. He finally finds its measure in an imagined scene of Asad returning to his shop immolated in the riots:

The walls are gone; only the concrete floor remains. He gasps when he takes this in. Around him is evidence of a will to obliterate him, to scorch and burn him until he is no longer a presence on this earth. It is in his history to be obliterated. It is in Sadicya's. (p. 284)

As a Galgale, Sadicya's obliteration is also ethnic or racial, an occlusion which Asad himself rails against even as he finds it rearticulated amongst the Somali community in Kansas. The protection Asad offers her helps repair the violence that the 'pogroms' in the townships (p. 324) had inflicted on him

\section{Transnational Migrations}

Steinberg's lexical evocation of Russian anti-semitism gives a transnational twist to the brutality of Asad's experience. Sharpe effects a similar twist in her discussion of the wake's 'weather' or the repeating climatic conditions hostile to Black lives. As the narrator of African Titanics reports, good weather conditions are essential for the crossing, but do not determine its ultimate success: 
And when the migrants reach the shore, they are often returned to the hold in the form of the camp, the Lager, the detention center, and so on, and they may be returned to the ship. Cast behind, set adrift, once again. ${ }^{34}$

Sharpe's evocation of the camp is almost inevitable given wake work's broad compass and indeed the history of the camp as a mode of social control born in the laboratory of colonialism. ${ }^{35}$ Yet the deployment of the German loanword Lager, the diffusion of which in English depends largely on the work of the Italian Jewish writer Primo Levi, makes an incursion into Italian postcoloniality. In the concluding chapter of The Black Atlantic, Paul Gilroy looks to Levi for some understanding of what 'racial slavery must have meant'. He sees a parallel between how Levi figures the prisoners' dehumanization through their forced journey and their subsequent 'condition of namelessness' and 'the literature and history of racial slavery in the new world'. ${ }^{36}$ Just as Levi moved beyond conventional, realist strategies of writing, Gilroy finds in the non-realist narrative strategies of black writers such as Toni Morrison the necessary resource through which to gain an 'imaginative proximity to forms of terror that surpass understanding and lead back from contemporary racial violence, through lynching, towards the temporal and ontological rupture of the middle passage'. ${ }^{37}$ Both Gilroy and Sharpe invoke Morrison's Beloved, her novel of haunting and haunted maternity in slavery's wake, anticipating Saidicya's dissident maternity in its contorted and convulsed temporalities. ${ }^{38}$

For Gilroy, the discursive positionality of slavery's afterlife (in which Asad's narrative is played out) oscillates between 'lived crisis and systemic crisis'. ${ }^{39}$ Steinberg's well-informed biography might be regarded as a delineation of the latter. It is a finely crafted, chronologically arranged interpretation of months of dialogue in which the competing perspectives of author and subject are constantly called into question. For Asad, Steinberg is both a financial resource and by virtue of his whiteness a shield against possible aggression. Steinberg's perception of his subject's unease opens up a space in his project as investigative journalist: 'It was a gift. In that moment, he gave me the ink with which I have written this book' (p. 293). Steinberg re-writes or translates Asad's 
existential fear in the 'orthography of the wake'. Yet as I have noted, Steinberg is also aware that Asad has smudged that ink through his praxis of imagining otherwise. A Man of Good Hope contains three political maps which chart Asad's journeys across state borders, as well as his own drawings of personal spaces where he lived as a child. Their inclusion allows for the expression of the political framework that underpins his life and its multiple displacements (the details of which he, unlike Steinberg, is largely ignorant), and of the affective moments of respite as he moved across the continent. These contrasting visual representations correspond to two different cognitive perspectives within the wake. Asad's drawings, I would suggest, are examples of what Gilroy calls the 'expressive counterculture' of transnational Black experience evidenced in the two texts I have discussed. Neither adheres to the comfort of a national paradigm or even a predicable postcolonial one, nor offers a simple corrective to the misrepresentational dysgraphia of the wake by setting out a better, more accurate, or more humane version of events or interpretative frame. Both, I would suggest, invite the reader to inhabit the angry, fearful, and creative modality of being that swimming 'against them waves' and living in the contradictions of the wake entails.

\section{The Postcolonial Afterlife of the Wake}

As already mentioned, Italy as a former colonial power seems barely to feature in these narratives of postcoloniality. In A Man of Good Hope, the only reference is to some Somali migrants Asad meets in Ethiopia who are planning to go there. In African Titanics, however, the return of the colonial past returns the narrator to his point of departure. Arrested by the Tunisian police, and in order to avoid immediate expulsion, the narrator and his companions deny having entered the country from Libya. Their story unravels when the police discover a Libyan banknote, kept as a souvenir, in the pocket of one of the travellers. The banknote shows the face of Omar al-Mukhtar, the Libyan national hero who fought against Italian occupation until his execution in 1931. Two weeks later, the narrator has been repatriated to Eritrea. This postcolonial remnant or relic works across boundaries of space, time, and citizenship to solicit a flexible, transnational, yet 
localized, praxis of critical analysis. Wake work requires a historically attentive mode of investigation to capture its purchase.

${ }^{1}$ Nipsey Hussle, 'Dedication', Victory Lap (2018).

2 The life jacket has become an icon of humanitarian intervention in the Mediterranean. See for example its recurrence in the work of photographer Mathieu Willcocks's 'Mediterranean Migration', a series of images taken by him in the course of six months aboard a rescue vessel:

https://www.mathieuwillcocks.com/ (accessed 18 May 2019). See also Kaya Barry, 'Art and materiality in the global refugee crisis: Ai Weiwei's artworks ad the emerging aesthetics of mobilities,' Mobilities, 14:2 (2019), 204-17.

${ }^{3}$ MSF estimate that 2,160 people died crossing the Mediterranean in 2018 alone. See https://www.msf.org.uk/country/mediterranean-search-and-rescue (accessed May 18 2019).

${ }^{4}$ For an incisive account of the Black Mediterranean, creativity and issues of citizenship especially in relation to Italian postcoloniality see SA Smythe, "The Black Mediterranean and the Politics of Imagination', Middle East Report (Spring 2018), 3-9. https://merip.org/magazine/286/.

${ }^{5}$ Saidiya Hartmann, Lose your Mother: A Journey along the Atlantic Slave Route (New York: Farrar, Strauss and Giroux, 2007), p. 6.

${ }^{6}$ Cristina Lombardi-Diop and Caterina Romeo (eds), Postcolonial Italy:

Challenging National Homogeneity (New York: Palgrave Macmillan, 2012), p. 4.

${ }^{7}$ Christina Sharpe, In the Wake: On Blackness and Being (Durham: Duke University Press, 2016).

${ }^{8}$ On 7 April 2019, the Eritrean community held a memorial service for Nipsey Hussle at the Medhani-Alem Eritrean Orthodox Tewahdo Church in Los Angeles. Attended by hundreds of people, the service reiterates the multiple logics of the wake identified by Sharpe.

${ }^{9}$ Sharpe, In the Wake, p. 15.

10 Ibid. p. 20.

${ }^{11}$ My essay speaks to recent scholarship which has extended the idea of Italian postcoloniality by looking at authors with family ties to Italy's former colonies, but who write in languages other than Italian. Some important work has been started in this area. A number of the essays in Brioni and Gulema's invaluable edited volume look at Italian colonialism and its legacy from the perspective of Africa: Simone Brioni and Shimelis Bonsa Gulema, The Horn of Africa: Colonial, 
Postcolonial and Transnational Encounters (Oxford: Peter Lang, 2018). For a discussion of intergenerational cultural memory in the work of writers with familial links to former Italian colonies in the Horn of Africa now resident in a variety of different locations see Emma Bond, "Let me go back and recreate what I don't know": Locating Trans-national Memory Work in Contemporary Narrative', Modern Languages Open (2016), https://doi.org/10.3828/mlo.v0i0.134.

${ }^{12}$ Abu Bakr Khaal, African Titanics, translated by Charis Bredin (London: Darf Publishers, 2014). The title refers to the precarious vessels in which migrants cross the Mediterranean hoping to reach Europe. The original version was in Arabic, one of the most widely used languages in Eritrea, and was published in London by Dar al Saqi (2008), and re-issued in Damascus by Al Naya (2009). I am grateful to Orhan Elmaz for his invaluable help in tracking down these publication details.

13 Jonny Steinberg, A Man of Good Hope: One Man's Extraordinary Journey from Mogadishu to Tin Can Town (London: Vintage, 2015). See Nick Mulgrew, 'The Subject as Writer: Substituting Discourse and Story in Jonny Steinberg's A Man of Good Hope,' Journal of Southern African Studies, 44:6 (2018), 1023-38 for a discussion of Steinberg's authorial strategies in particular the textual construction of the ethically driven relationship with his subjects.

${ }^{14}$ For an expansive account of the transnational Somali presence in South Africa see Samadia Sadouni, Muslims in Southern Africa: Johannesburg's Somali Diaspora (London: Palgrave Macmillan, 2019).

15 Khaal, African Titanics, p. 59.

16 On suicide during and after the middle passage, see Terri L. Snyder, The Power to Die: Slavery and Suicide in British North America (Chicago: University of Chicago Press, 2015).

17 Steinberg, A Man of Good Hope, p. 293.

${ }^{18}$ Although very different in detail, this account is an uncanny reiteration of the hanging of an unnamed enslaved girl on board the Recovery who became another trope of abolitionist discourse. Hartman's analysis of the competing versions of the circumstances of her death includes a critical reflection on her own participation in the necrology: Hartman, Lose your Mother, pp. 136-53. ${ }^{19}$ Sandro Mezzadra and Brett Neilson, Border as Method, or the Multiplication of Labor (Durham: Duke University Press, 2013), p. 275.

${ }^{20}$ Pier Paolo Frassinelli, 'Living in Translation: Borders, language and community in NoViolet Bulawayo's We Need New Names,' Journal of Postcolonial Writing, 51:6 (2015), 711-22 (p. 720).

21 The return and presence of ancestral spirits in postcolonial fiction by writers of West African origin is commented on by Cristina Lombardi-Diop, 'Ghosts of Memories, Spirits of Ancestors: Slavery, the Mediterranean, and the Atlantic', in Recharting the Black Atlantic: Modern Cultures, Local Communities, Global Connections, eds. Annalisa Oboe and Anna Scacchi. (London: Routledge, 2008), pp. 162-180, see pp. 171-77 in relation to this point. The Liberian Malouk's ancestral myths fit well in this tradition.

${ }^{22}$ In her reading of the novel, Janet Wilson contends that Malouk's final poem provides a form of closure. I would argue that reading the poem 'in the wake' demands a recognition that the 'suffering' Wilson points too is not over at all. See Janet Wilson, 'Novels of Flight and Arrival: Abu Bakr Khaal's African Titanics 
(2014 [2008]) and Sunjeev Sahota, The Year of the Runaway (2015)', Postcolonial Text (2017), 12.3-4.

${ }^{23}$ For a discussion of cultural practices of migrant burial and remembrance see Ottavia Salvador and Fabrizio Denunzio, Morti senza sepoltura: tra processi migratori e narrativa neocoloniale (Verona: Ombre corte, 2019) With particular reference to the events of October 2013 discussed later in this essay, see Gianluca Gatta, 'Lampedusa, 3 ottobre 2013. Vita, morte, nazione e politica nella gestione dei migranti', Studi culturali, XI:2 (2014), 323-32. ${ }^{24}$ In 1781, over 130 enslaved Africans were thrown from the Zong reputedly to save dwindling supplies of water and food. The owners subsequently made an insurance to compensate for the loss of 'cargo.' The episode is a key moment in abolitionist history. See Sharpe, In the Wake, pp. 34-38. Also Ian Baucom, Specters of the Atlantic: Finance, Capital, and the Philosophy of History (Durham: Duke University Press, 2005). It is estimated that on the crossing of October 2 2013, the traffickers would have made almost half a million euros.

${ }^{25}$ Sharpe, In the Wake, pp. 53-57. Her account includes fragments of survivor testimony from the boat.

${ }^{26}$ The Eritrean-born, Italian film-maker Dagmawi Yimer's animated film AsmatNames in Memory of all the Victims of the Sea (2015) made specifically to commemorate those who died in the shipwreck of 3 October 2013 tackles this silence through the female narrator's reading of the names of all the dead. The film can be seen at https://vimeo.com/114343040 (accessed 20 May 2019) 27 See, for example, Cindy Horst, Transnational Nomads: How Somalis cope with refugee life in the Dabaab camps of Kenya (New York and Oxford: Berghahn, 2006).

${ }^{28}$ Frassinelli, Living in Translation, p. 714.

${ }^{29}$ I take the term from Françoise Lionnet and Shu-mei Shih (eds), Minor

Transnationalism (Durham: Duke University Press, 2005).

30 Sharpe, In the Wake, p. 113.

${ }^{31}$ Having been challenged by Asad to find out more about the Galgale, Steinberg uses Sadicya as a means through which to inform the reader about recent Somali history, and in this case the clan system (pp. 278-81).

${ }^{32}$ Alan Sekula and Noël Burch, The Forgotten Sea (2010). The film essay

investigates global maritime trade. It fails to mention the Middle Passage or the contemporary trafficking of migrants. Sharpe is correct to point to the extraordinary, yet eloquent nature of this omission. Sharpe, In the Wake, pp. 2526.

33 Sharpe, In the Wake, p. 77.

${ }^{34}$ Ibid, p. 108.

35 On this point see David Atkinson, 'Encountering Bare Life in Italian Libya and

Colonial Amnesia in Agamben,' Agamben and Colonialism, Marcelo Svirsky

and Simone Bignall (eds) (Edinburgh: Edinburgh University Press, 2012), pp. 155-77.

${ }^{36}$ Paul Gilroy, The Black Atlantic: Modernity and Double Consciousness (London: Verso, 1993), p. 215.

37 Ibid. p. 222.

38 Toni Morrison wrote the introduction to the recent English translation of Levi's complete works soldering an increasingly widely perceived linkage 
between historical experiences which all the while remain distinct in their specificity: Toni Morrison, 'Introduction,' The Complete Works of Primo Levi, translated by Ann Goldstein et al. (New York: Liveright, 2015), pp. xi-xiii.

${ }^{39}$ Gilroy, The Black Atlantic p. 39. 